\title{
CRITICAL SUCCESS FACTORS FOR SMES PERFORMANCE: EMPIRICAL EVIDENCE
}

\author{
Okoli Ifeanyi .E. Nuel, Ph.D \\ Lecturer, Department of Entrepreneurial Studies, \\ Nnamdi Azikiwe University, Anambra State, Nigeria \\ ie.okoli@unizik.edu.ng \\ Nnabuife Ezimma K., Ph.D \\ Lecturer, Department of Business Administration, \\ Nnamdi Azikiwe University, Anambra State, Nigeria \\ ezimmannabuife@gmail.com \\ Allison Pat, Ph.D \\ Lecturer, Department of Business Management, \\ Godfrey Okoye University, Enugu State, Nigeria \\ patukallison@yahoo.com
}

\begin{abstract}
This study seek to examine the extent critical success factors like top management support, entrepreneurial orientation and customers focus aid in the performance of small and medium enterprises SMEs in Anambra State Nigeria. A survey research design was applied for this study. Data was collected through survey questionnaires applied to business owners and senior managers working in SMEs in Anambra State, using purposive sampling technique. Simple Linear regression was applied to test the hypotheses. The study found out that critical success factors are significant and positively related to SMEs performance. This is due to the fact that all the decomposed variables of critical success factors and the SMEs performance had significant positive relationships with each other. The study recommends that small and medium enterprises should always take decisive and calculated risks to offer better products to the target customer and that customer requirements should dominate all activities of small and medium enterprises at all times. Management of small and medium enterprises should deal with the tendency to offer what it wants customers to get.
\end{abstract}

Keywords: Critical Success factors, Performance, Top management support, Entrepreneurial orientation, Customer focus. 


\section{INTRODUCTION}

Firm's growth is a central topic in the literature on entrepreneurship, strategic management and industrial organization, among others. For a single business entity, growth is the evidence of an entrepreneur's business return and self-fulfillment. Growth is also a means of survival for young and small businesses, where young firms are seen as less likely to fail than non-younger firms (Stam, Suddle, Hessels, \& Von Stel, 2006). Both researchers and policy makers interested in expansion, focus on rapidly growing firms and on small and medium enterprises (SMEs). Since the expansion and growth of firms have proven to be a condition for competitive advantage both at the level of individual firms and at the level of the economy in general, the phenomenon of critical success factors for the growth of SMEs has become a focus of research.

Christensen, Johnson, \& Rigby (2002) posit that entrepreneurial activities are one of the key driving forces to a small and medium enterprises (SMEs) growth. However, certain aspects of entrepreneurial activities need to be considered when a person wants to be an entrepreneur, such as preparation before starting the business, while doing business and also after plans to quit from the business sector (Frank, Lueger, \& Korunka, 2007). Despite government introducing several development programs in helping entrepreneurs to grow with the intention to realize its vision, these entrepreneurs are still losing their competitive advantage in the global business environment due to their low productivity and poor performance (Tehseen, Sajilan, Ramayah, \& Gadar, 2015). Therefore it is crucial to identify critical success factors that can improve competitiveness and reduce the small and medium enterprises (SMEs) growth gap in term of contribution to the economy.

There exist extensive literature on SMEs growth with keen focus on factors that facilitate or constrain their success and how such success contributes to economic development. Past studies have been central in identifying a multiplicity of factors that influence success/failure of enterprise, which can be categorized into internal and external factors. The internal factors refer to enterprise-specific issues such as managerial skills, human capital, financial management, and demographics and organizational innovation while external factors include macroeconomic factors, political and institutional forces, market opportunities, and socio-cultural factors (Olawale \& Garwe, 2010; Thandeka, 2008).

Mwangi, Sejjaaka, Maina, Kairo, Rotich, Owino, \& Mindra (2013) posit that numerous studies on SMEs across developing countries have focused on the identification of specific factors that affect their success and sustainability. According to Al-Mahrouq (2010) the benefits of these factors are peculiar to different countries. For example in Malaysia, Rose, Kumar \& Yen (2006) suggested that the success for enterprises was driven by factors such as; personal initiative, education, working experience, managerial and technical skills, and parental commitment business are critical in business success. Al-Mahrouq (2010) listed five factors that were central to the success of enterprise in Jordan, and among them included; the technical procedures and technology, firm structure, financial structure, marketing, productivity and human resource structure. A recent study conducted by Vyas, Raitani, Roy, \& Jain (2015) found that critical success factors such as supportive organizational factors, fast and responsive services, targetbased marketing, SME banking policy and model, and the improvement in customer services are 
critical for the success of SMEs operating in the banking industry in India. Chong, Shafaghi, \& Tan (2011) investigated critical success factors for firms doing business in China and they advocated a combination of internal critical factors (successful customer relationships, security and trust, understanding of information, IT infrastructure, management support, supply chain facilities) and external critical areas (global competitiveness, government commitments, cultural considerations) in developing successful business sustainability and business e-commerce.

Studies across African continent on SMEs have largely focused on the causes of business failures. A study by Tushabomwe-Kazooba (2006) in Uganda, found that political, social and economic issues coupled with poor management were the main factors that led to the collapse of enterprises. For Nigeria, the enterprises which are 95\% involved in manufacturing activity are being hindered by the insecurity, corruption and poor infrastructure to prevent them from being growth enterprises. Most of the firms are small because the private sector is new and the legal and financial obstacles to capital accumulation (Kauffmann, 2005). In Kenya, a study by Bowen, Morara, \& Mureithi, (2009) established that micro and small enterprises were faced with numerous challenges among them including; ferocious competition across different sectors, security uncertainties, debt management issues, inadequate capital, and lack of innovation. In view of the above, it is clear that research on critical success factors for SMEs growth is still at a developing stage. This study intends to fill the gap by identifying the relationship between critical success factors and SMEs growth. The outcome of this study will be useful for entrepreneurs as well as scholars in generating a framework that can improve overall organizational growth in emerging economies. The research objective of this study is to examine the relationship between critical success factors (top management support, entrepreneurial orientation and customer focus) and SMEs performance.

\section{REVIEW OF RELATED LITERATURE Critical Success Factors (CSFs)}

Critical Success Factors (CSFs) can be defined as those small number of areas in which satisfactory results will assure successful competitive advantage for the individual, department or organization (Bullen \& Rockart, 1981). Saraph, Benson, \& Schroeder (1989) saw CSFs as those critical areas of planning and managerial action that must be practiced to achieve effectiveness. Critical success factors (CSFs) are elements that are vital for a successful strategy and could affect the performance in a either positive or negative direction (Raravi, Bagodi, \& Mench, 2013). Freund (1988) defines CSFs as those things that must be done if a company is to be successful, thus those factors within the firms that helps organizations to be favourable on a competitive market. Boynton \& Zmud (1984) define CSF as those few things that must go well to ensure the success of a manager or an organization and, therefore, represent those managerial or areas of business that will receive special attention and continuous to achieve high performance. CSFs include issues vital to an organization's current operational activities and to its strategic success.

Critical success factors are inspired by the issue of optimum match between environmental conditions and business characteristics, i.e., the core of business strategy. It is assumed that the surrounding environment has certain fundamental requirements and limitations, threats and 
opportunities, to which firms must align their strategy, skills and resources to achieve success. No organization can afford to develop a plan that does not give adequate attention to the major factors underlying success in the industry (Rockart, 1979). De Vasconcellos, Sousa, \& Hambrick (1989) study contributed with quantifiable support that organisation with higher ratings on CSFs than competitors on the market possess strengths in the given areas and will outperform the competition. This means that when an organization wants to do better than others, the manager should focus on a few CSFs rather than a number of reasons. Consequently Boynton \& Zmud (1984) argues that when an organization's CSFs are identified they need careful attention, as it is vital for the organizations operating activities and its future prosperity.

The critical success factors are vital for running of business due for many reasons (Wong, 2005). It assists to ensure that the essential factors will receive thorough and continuous management scrutiny. The CSFs perform the task of forcing managers to provide a proper procedure for the factors and require an examination of each. Understanding CSFs makes it possible to define the amount of information an organization will collect and prevent more expensive collection of data than necessary. Rockart (1979) recognizes the difference between five important approaches to critical success factors:

a) The industry: e.g., demand characteristics, technology employed, product characteristics etc. These can also affect all competitors within the industry, but their impact will vary according to the features and understanding of each industry sector.

b) Competitive strategy and industry position of the business: Is determined by the history and competitive positioning in the industry.

c) Environmental factors: The macroeconomic influences that affect all competitors within an industry, and over which the competitors have little or no influence, e.g., demographics, economic and government legislative policies etc.

d) Temporal factors: Areas within a business causing a time-limited distress to the implementation of a chosen strategy, e.g., lack of managerial expertise or skilled workers.

e) Managerial position: i.e., the various functional managerial positions in a business have each their generic set of associated critical success factors.

\section{Top Management Support}

Top Management support is executive management's willingness to authorize and delegate power to provide the necessary resources (Project Management Institute, 2008). Top management support is seen as the kind of support that the managers expects from the top management for the project and for himself as a leader (Pinto \& Slevin, 2006). The committed and strong leadership at top management level is one of the major critical factors to entrepreneurial success which can moderate the accomplishment of successful enterprise. Top management support refers to backing and commitments from top industry leaders for projects as well as strategies implementation (Garrett \& Neubaum, 2013).

Top management support plays a critical role in the entrepreneurial outcomes that have been investigated as a critical factor for firm's success. Liu, Zhang, Keil, \& Chen, (2010) opined that top management support is one of the most important critical factors for successful 
implementation of projects. Flynn, Schroeder \& Sakakibara (1995) argues for the need of top management commitment, as it has a large influence towards the overall strategic direction of the organization. General consensus stated that top management support must be supported and demonstrated, by sharing information and vision with others at all levels (Demirbag, Tatoglu, Tekinkus, \& Zaim, 2006; Fotopoulos \& Psomas, 2009; Salaheldin, 2009; Turkyilmaz, Tatoglu, Zaim, \& Ozkan, 2010). The importance of top management support being an active stakeholder is a strong factor that must be present throughout the process of strategy implementation to ensure successful enterprise. Top management support is a combination of gaining attention and providing resources to entrepreneurs for successful accomplishment of objectives.

Many empirical researches show evidence that top management support is fundamental, and remain critical in order to achieve values. Top management's responsibility includes communicating the company's strategy to all members of the organization, providing financial assistance for training programs, and motivating employees to innovate and solve problems (Al Shaar, Khattab, Alkaied, \& Manna, 2015; Umble, Haft, \& Umble, 2003). Lack of top management support is a critical barrier (Somers \& Nelson, 2004) because the top leadership plays an important role throughout the life of an enterprise. In this regard, Iqbal, Long, Fei, Ba'ith, \& Bukhari (2015) showed that top management support plays a vital role in ensuring the success of a business by facilitating the acquisition of timely resources. Similarly, Fernandes, Lourenco, \& Silva (2014) found that leadership attitude and support of the top management can promote organizational innovation.

Based on these discussions, therefore the following hypothesis is proposed:

H1: Top management support is positively related to SMEs performance.

\section{Entrepreneurial Orientation}

Entrepreneurial orientation (EO) is a significant factor for enterprise success (Wang, 2008). Entrepreneurial orientation refers to tendencies, processes and practices that lead to new or existing business or services (Walter, Auer \& Ritter, 2006). Entrepreneurial orientation has been proposed as the decision making process and activities used by entrepreneurs that lead to a new entry and support for business activities (Lumpkin \& Dess, 2001; Kropp, Lindsay \& Shoham, 2006). At the organization level, entrepreneurial orientation is defined as the strategy making processes that offer firms with a basis for decision making and business actions (Rauch, Wiklund, Lumpkin, \& Frese, 2009).

Based on varieties of corporate entrepreneurship, entrepreneurial orientation includes five characteristics such as innovativeness, riskiness, proactiveness, competitive aggressiveness and autonomy (Walter et al., 2006). Apart from other dimensions of entrepreneurial orientation, innovativeness has been considered as one of the most important strategic orientations of firms to achieve long-term success (Noble, Sinha, \& Kumar, 2002), and significantly impacted on business performance (Baum, 1995; Rauch \& Frese, 2000; Utsch \& Rauch, 2000).

Several studies have found that firms demonstrating more entrepreneurial orientation perform better (Wiklund \& Shepherd, 2005) and explore opportunities for new innovations leading to market entry and advantage (Covin \& Miles, 1999; Lumpkin \& Dess, 1996). A significant 
review process has focused on the benefit of top management (Hambrick \& Mason, 1984) and entrepreneurial behaviour (Covin \& Slevin, 1989) in determining firm performance. It has been researched mainly in its relation to the firm performance and has been constantly revealed to be positively significant (Gupta \& Batra, 2015).

Using descriptive research design on a sample of 1141 small and medium-sized companies of which 740 microenterprises, Civelek, Rahman \& Kozubikova (2016) identified and examined the gender differences, the level of education of the entrepreneurs and the age of the enterprises regarding entrepreneurial tendency in the sector of microenterprises in the Czech Republic. The results showed that educated micro-entrepreneurs at the university were more innovative and autonomous compared to micro-entrepreneurs with less education. The results further revealed that younger micro firms are more proactive, innovative and willing to take risks than the older micro firms. Baker, Mahmood \& Ismail (2015) explored survey research design and Partial Least Square (PLS) methodology on a sample of 500 small and medium enterprises (SMEs) owners/managers that were randomly selected from registered small and medium enterprises (SMEs) to investigate if entrepreneurial orientation, strategic improvisation and performance of SMEs in Malaysia are significantly related. The result showed that there is a significant relationship between entrepreneurial orientation and the performance of SMEs. Furthermore, Jabeen \& Mahmood (2014) elucidate that firms who adopt entrepreneurial orientation can frequently innovate and are willing to take risks in their strategies that ultimately leads them to superior performance.

Based on these discussions, the following hypothesis has been developed:

H2: Entrepreneurial orientation is positively related to SMEs performance.

\section{Customers Focus}

Customer focus is the extent to which a company can continually meet customer expectations and needs (Zhang, Linderman, \& Schroeder, 2012). It occurs when firms attain its strategic objectives. Customer focus is considered as one of the critical success factors in business. Customer focus is vital in organizations as it refers to the process of identifying and establishing, maintaining, enhancing and when necessary terminating relationships with customers and other stakeholders (Gronroos, 2004). A customer focus is essential as it is known as a strong contributor to business profitability, competitive advantage, and a hallmark of successful business (Nwokah \& Maclayton, 2006; Ziggers \& Henseler, 2015).

Sila (2007) believes that what determines whether an organization is successful in the future is not the satisfaction of its customers and its ability to meet the needs of a full-time business effectively and efficiently. Of course, paying attention to customers is a key factor for a company's growth. It emphasizes the importance of creating customer value in organizational development. Modern business entrepreneurs must be able to ensure that they have a large customer base so that they can respond to rapidly changing customer interests (Saravanan \& Rao, 2006). On the whole, the value of a company comes from the customer's desire and wants to be satisfied, the way in which the customer's focus is on solid profits is not always clear as it emerges based on the research associated with the literature (Noble, et al.,2002). 
Asikhia (2010) depicts that customer orientation and focus and the organizational performance are positively related. The support of having a high degree of customer focus in SMEs is likewise addressed in the study conducted by Ahire \& Golhar (1996), who went on to argue that the focus of customers may be higher in SMEs due to their nearness to the customers. SMEs' should not only look at customers as a source of revenue and profits for the company, but also a resource for acquiring and sustaining competitive advantage.

Based on these discussions, the following hypothesis has been developed:

H3: Customer focus is positively related to SMEs performance.

\section{Small and Medium Enterprises (SMEs) Performance}

Vassilakis \& Besseris (2009) see organizational performance as the achievement of the firm's organizational objectives. According to Cho \& Dansereau (2010), organizational performance refers to the performance of a firm as compared to its goals and objectives. Organizational performance comprises the output or results of an organization as outlined in its expected outcomes (Tomal \& Jones, 2015). Organization focuses on continuous performance, because performance improvement enables organizations to grow (Gavrea, Ilies, \& Stegerean, 2011). Organizational performance refers to the concept of assessing the position of the firms in the market and the ability of the firms to meet the needs of all stakeholders (Griffin, 2003; Lo, Mohamad, Ramayah and Wang, 2015).

According to Cho, (2011) organizational performance is the result of many business factors such as work process, team/group communication, business culture and image, policies, leadership, and climate that encourage innovation, creativity and loyalty. Ramamoorthy (2007) defines organizational performance as the result of the organizations' achievement or operations in three dimensions: organizational, financial effectiveness, and operational efficiency. Non-financial and operational performance includes market share, product innovation, market effectiveness, and financial quality. Organizational performance is a multinational variable or construct that can be measured using various indicators including product quality effectiveness, customer satisfaction, and financial performance.

Measuring the performance of any organization is a difficult task as it provides information on the quality of processes performed within the organization, helps in developing strategic plans; assess the fulfillment of organizational objectives (Almajali, Masa'deh, \& Tarhini, 2016). Usually using financial measures organization assess their performance, however these measures have been criticized as encouraged short-term views, produced management conflicts, not have strategic focus, and failed to provide information about customer requirements and the level of competitors. The financial performance of a company can be measured based on the amount of money collected, return on investment, level of performance, return on assets, growth in the stock market, market growth and profitability.

There are many measurement techniques available, for the companies who want fulfillment these objectives and increase organizational performance, among which balanced score card (BSC) is one of the most valuable performance measurement and management method that is commonly 
known and used. Kaplan \& Norton (1992) developed BSC included non-financial indicators in performance measurement and management systems. This method provides a comprehensive framework for managers that help them to modify the strategies of their organizations into a set of performance measures.

\section{METHODOLOGY}

The study adopted a survey research design. This study was conducted out in Anambra State. The population of this study consists of business owners and senior managers currently working in SMEs in Anambra State. In selecting the respondents, we adopted a method of purposive sampling. Both secondary and primary data were used to achieve the objectives of this study. Secondary data were collected from Anambra State Ministry of Trade, Industry and Commerce, journals, books, thesis, dissertations, working papers, and the Worldwide Web. Primary data was collected by detailed survey using questionnaire.

The instrument for data collection was the questionnaire, and all scales were redesigned from previous studies that have improved the state of development as well as the developing economy. This question is divided into two parts. The first section requires respondents to state fifteen (15) items on three critical success factors, namely top management support, entrepreneurial orientation and customers focus; and the second section requires respondents to evaluate the performance of their perceived SMEs.

Prior to data collection, preliminary checks through self-assessments and 20 SMEs were conducted to determine whether respondents understood the questions as well as to determine if any further modification of the items and format was necessary. After refining the wording of some of the measures, a total of three hundred and fifty (350) copies of questionnaires were distributed personally to selected SMEs. The researcher ensured the anonymity of respondents before joining in the survey to reduce the responses people were looking for. Out of the 350 distributed copies of questionnaires, 312 copies of the questionnaires were returned and used for statistical analysis, indicating a response rate of $89.14 \%$. The questionnaire was validated using face and content validity. The reliability analyses were run with Cronbach Alpha to depict the internal consistency of the key variables (see table 1 below). The alpha coefficients showed that top management support, entrepreneurial orientation, customer focus, and SME performance scored $0.886,0.936,0.867$, and 0.722 , respectively.

Table 1: Reliability analysis

\begin{tabular}{lcc}
\hline Variable & Number of items & Cronbach's Alpha \\
\hline Top Management Support & 5 & 0.886 \\
Entrepreneurial Orientation & 5 & 0.936 \\
Customer Focus & 5 & 0.867 \\
SME Performance & 5 & 0.722 \\
\hline
\end{tabular}

According to Nunnally (1978) if the Cronbach's Alpha value goes beyond 0.7, it represents satisfactory internal consistency. Since the overall reliability of questionnaire is above 0.70 , the 
questionnaires were administered and collected personally by the researcher to ensure better response rate. The data analysis was performed using Statistical for Social Science (SPSS) tools. Linear regression analysis was carried out to determine the degree of relationship between the independent variables and the dependent variable. Significance level was set at $p=0.05$.

\section{STATISTICAL TEST AND RESULTS}

The inferential statistical tool used was linear regression. This was used to find out the extent of relationship between critical success factors and SMEs performance.

\section{Hypothesis One:}

$\mathbf{H}_{1}$ : Top management support is positively related to SMEs performance.

Table 2: The extent of Relationship between Top Management Support and SMEs Performance

\begin{tabular}{lccccc}
\hline Variable & Beta & t value & R Square & F value & Sig. \\
\hline (Constant) & & 22.077 & & & .000 \\
Top Management Support & .503 & 10.258 & .253 & 105.233 & .000 \\
\hline
\end{tabular}

Dependent Variable: SMEs performance

The result showed a positive, statistical relationship between top management support and SMEs performance $\left(\right.$ Beta $\left.=0.50, \mathrm{t}=10.258, \mathrm{r}^{2}=.253, \mathrm{~F}=105.233, p<.001\right)$. Therefore, the alternate hypothesis was not rejected. This explained that top management support was a key predictor of SMEs performance. The result indicated that $25 \%$ change in SMEs performance was related to change in top management support. This means that top management support significantly lead to SMEs performance. The survey specifies that top management support exerts low level of influence on SMEs performance. Therefore, high top management support translated to high SMEs performance and vice versa.

\section{Hypothesis Two}

$\mathbf{H}_{2}$ : Entrepreneurial orientation is positively related to SMEs performance.

Table 3: The extent of Relationship between Entrepreneurial Orientation and SMEs Performance

\begin{tabular}{lccccc}
\hline Variable & Beta & t value & R Square & F value & Sig. \\
\hline (Constant) & & 23.403 & & & .000 \\
Entrepreneurial Orientation & .470 & 9.370 & .221 & 87.791 & .000 \\
\hline Depend
\end{tabular}

Dependent Variable: SME Performance

The result ascertained a positive, statistical influence of entrepreneurial orientation on SMEs performance $\left(\right.$ Beta $\left.=0.47, \mathrm{t}=9.370, \mathrm{r}^{2}=.221, \mathrm{~F}=87.791, \mathrm{p}<.001\right)$. Hence, the alternate hypothesis was not rejected. The research established that entrepreneurial orientation was an important factor which influences SMEs performance. It was indicated that $22 \%$ change in SMEs performance was linked to change in entrepreneurial orientation. This implied that entrepreneurial orientation exerted low level of influence on SMEs performance; therefore, the higher entrepreneurial orientation, the higher the SMEs performance and vice versa.

\section{Hypothesis Three}

$\mathbf{H}_{3}$ : Customer focus is positively related to SMEs performance. 
Journal DOI: 10.46654/ij.24889849

Table 4: The extent of Relationship between Customer Focus and SMEs performance.

\begin{tabular}{lccccc}
\hline Variable & Beta & $\mathrm{t}$ value & $\mathrm{R}$ Square & $\mathrm{F}$ value & Sig. \\
\hline (Constant) & & 15.131 & & & .000 \\
Customer Focus & .653 & 15.161 & .426 & 229.849 & .000 \\
\hline
\end{tabular}

Dependent Variable: SME Performance

The result determined a positive, statistical influence of customer focus on SMEs performance $\left(\right.$ Beta $\left.=0.65, \mathrm{t}=15.161, \mathrm{r}^{2}=.426, \mathrm{~F}=229.849, p<.001\right)$. Thus, the alternate hypothesis was not rejected. It was indicated that customer focus significantly influenced SMEs performance. The result specified that $43 \%$ change in SMEs performance was associated with change in customer focus. This explained that customer focus exerted moderate level of influence on SMEs performance. Higher customer focus translated to higher SMEs performance and vice versa.

\section{Discussion of Findings}

The present study was conducted among SMEs in Anambra State with a view to examine the relationship between critical success factors and SMEs performance. The research ascertained statistical influence of top management support on SMEs performance. The result was in line with those of Al Shaar, Khattab, Alkaied, \& Manna, (2015), Iqbal, Long, Fei, Ba'ith, \& Bukhari (2015), Fernandes, Lourenco, \& Silva (2014), as well as Umble, Haft, \& Umble (2003). It has been maintained that top management communicates company's strategy to all members of the organization, provides financial support for training programs, and motivates employees to innovate and solve problems (Al Shaar, Khattab, Alkaied, \& Manna, 2015; Umble, Haft, \&Umble, 2003). Iqbal, Long, Fei, Ba'ith, \& Bukhari (2015) established that top management support plays a crucial role in ensuring entrepreneurial success by facilitating the provision of timely resources. Similarly, Fernandes, Lourenco, \& Silva (2014) found that leadership attitude and support of the top management tend to promote organizational innovation. Similarity of the results indicated that SMEs performance hinges on top management action and inactions.

On the second hypothesis, it was established that entrepreneurial orientation significantly relate with SMEs performance. The result was supported by works of Baker, Mahmood \& Ismail (2015), Jabeen \& Mahmood (2014), Wiklund \& Shepherd (2005), Covin \& Miles (1999), and Lumpkin \& Dess (1996). In a Malaysian survey, Baker, Mahmood \& Ismail (2015) determined a significant relationship between entrepreneurial orientation and the performance of SMEs. Furthermore, Jabeen \& Mahmood (2014) argued that firms who adopt entrepreneurial orientation tend to frequently innovate and are willing to take risks in their strategies that ultimately lead them to superior performance. It was found that firms which demonstrate more entrepreneurial orientation perform better (Wiklund \& Shepherd, 2005) and explore more opportunities for new innovations which lead to market entry and competitive advantage (Covin \& Miles, 1999; Lumpkin \& Dess, 1996). The results showed that entrepreneurial orientation was a key technique to SMEs performance.

The third hypothesis revealed a positive significant relationship between customer focus and SMEs performance. Asikhia (2010) and Ahire \& Golhar (1996) reported similar findings. Asikhia (2010) revealed that customer focus and organizational performance are positively related. Similarly, Ahire \& Golhar (1996) stressed that a high degree of customer focus leads to 
stronger SMEs. Customer focus was a basic strategic approach which ensures SMEs growth and sustainability.

\section{CONCLUSION}

The study concludes that critical success factors are significant and positively related to SMEs performance. This is due to the fact that all the decomposed variables of critical success factors and the SMEs performance had significant positive relationships with each other. As the firm grows, the entrepreneurs must be attuned to promoting company's strategic intention and its product and services, understanding market needs and customer feedback. Knowing the trends and what comes next as accurately as possible will allow firms survival.

\section{Recommendations}

Sequel of the findings and the conclusion, the study recommends that:

1. Management of small and medium enterprises (SMEs) should vigorously pursue and support novel by entertaining employee suggestions and criticisms.

2. Small and medium enterprises should always take decisive and calculated risks to offer better products to the target customer.

3. Customer requirements should dominate all activities of small and medium enterprises at all times. Management of small and medium enterprises should deal with the tendency to offer what it wants customers to get. 


\section{References}

Ahire, S.L., \& Golhar, D.Y. (1996). Quality management in large vs. small. Journal of Small Business Management, 34(2), 1-13.

Al Shaar, E. M., Khattab, S. A., Alkaied, R. N., \& Manna, A. Q. (2015). The effect of top management support on innovation: The mediating role of synergy between organizational structure and information technology. International Review of Management and Business Research, 4(2), 499.

Al-Mahrouq, M. (2010). Success Factors Of Small And Medium-Sized Enterprises ( Smes ): The Case Of Jordan Küçük Ve Orta Ölçekli İşletmelerde ( Kobi ) Başari Faktörleri : Ürdün Örneği. Anadolu University Journal of Social Sciences, 10(1), 1-17.

Almajali, D.A., Masa'deh, R.E., \& Tarhini, A. (2016). Antecedents of ERP systems implementation success: A study on Jordanian healthcare sector. Journal of Enterprise Information Management, 29(4), 549-565

Asikhia, O. (2010). Customer Orientation and Firm Performance among Nigerian Small and Medium Scale Businesses. International Journal of Marketing Studies, 2(1), 197- 205.

Baker H.A, Mahmood R, \& Ismail, N.N.H.N. (2015). Fostering small and medium enterprises through entrepreneurial orientation and strategic improvisation. Mediterranean Journal of Social Sciences; 481-487.

Baum, T. (1995). Managing human resources in the European tourism and hospitality industry: A strategic approach. London: Chapman and Hall.

Bowen, M., Morara, M., \& Mureithi, M. (2009). Management of business challenges among small and micro enterprises in Nairobi, Kenya. KCA Journal of Business Management, 2(1), 16-31.

Boynton, A.C., \& Zmund, R.W (1984) 'An Assessment of Critical Success Factors'. Sloan Management Review, 24, (4), 17-28.

Bullen, C. V., \& Rockart, J. F. (1981). A primer on critical success factors. Sloan School

Cho, J., \& Dansereau, F. (2010). Are transformational leaders fair? A multi-level study of transformational leadership, justice perceptions, and organizational citizenship behaviors. The Leadership Quarterly, 21(3), 409-421.

Cho, T. (2011). Knowledge Management Capabilities and Organizational Performance: An Investigation into the Effects of Knowledge Infrastructure and Processes on Organizational Performance. Unpublished PhD Thesis, University of Illinois.

Chong, W. K., Shafaghi, M., \& Tan, B. L. (2011). Development of a business-to-business critical success factors (B2B CSFs) framework for Chinese SMEs. Marketing Intelligence \& Planning, 29(5), 517-533. 
Christensen, C.M, Johnson, M.W. \& Rigby, D.K. (2002). Foundations for growth: how to identify and build disruptive new businesses MIT Sloan Management Review, 43 (3): 2231.

Civelek M, Rahman A, \& Kozubikova L. (2016). Entrepreneurial orientation in the segment of Micro-Enterprises: evidence from Czech Republic, International Journal of Entrepreneurial Knowledge; 72-89.

Covin, J. G., \& Miles, M. P. (1999). Corporate entrepreneurship and the pursuit of competitive advantage. Entrepreneurship: Theory \& Practice, 23(3), 47-63.

Covin, J.G. \& Slevin, D. (1989) Strategic Management of Small Firms in Hostile and Benign $\begin{array}{llll}\text { Environments. Strategic Management Journal, } & 10,\end{array}$ http://dx.doi.org/10.1002/smj.4250100107

De Vasconcellos, E.S., Sousa, J.A., \& Hambrick, D.C. (1989). Key success factors: Test of a general theory in the mature industrial product sector. Strategic Management Journal, 10(4), 367-382.

Demirbag, H., Tatoglu, E., Tekinkus, M., \& Zaim, S. (2006). An analysis of the relationship between TQM implementation and organizational performance: Evidence from Turkish SMEs. Journal of Manufacturing Technology Management, 1(6), 829-847.

Fernandes, A. A. C. M., Lourenco, L. A. N., \& Silva, M. J. A. M. (2014). Influence of Quality Management on the Innovative Performance/Influencia da Gestao da Qualidade no Desempenho Inovador/Influencia de la gestion de la calidad en el desempeno innovador. Revista Brasileira de Gestão de Negócios, 16(53), 575-593.

Flynn, B.B., Schroeder, R.G., \& Sakakibara, S. (1995). The impact of quality management practices on performance and competitive advantage. Decision Sciences, 26(5), 659-692.

Fotopoulos, C.V., \& Psomas, E.L. (2009). The structural relationships between TQM factors and organizational performance. The Total Quality Management Journal, 22(5), 539-552.

Frank, H., Lueger, M., \& Korunka, C. (2007). The significance of personality in business startup intentions, start-up realization and business success. Entrepreneurship and Regional Development, 227-251.

Freund, Y.P. (1988). Critical success factors. Strategy \& Leadership, 16(4), 20.

Garrett, R.P., \& Neubaum, D.O. (2013). Top management support and Initial strategic assets: A dependency model for internal corporate venture performance. Journal of Product Innovation Management, 30(5), 896-915.

Gavrea, C., Ilies, L., \& Stegerean, R. (2011). Determinants of organizational performance: The Case of Romania. Management \& Marketing, 6(2), 285-300. 
Griffin, K. (2003). Economic globalization and institutions of global governance. Development and Change, 34(5), 789-807.

Gronroos, C. (2004). The relationship marketing process: communication, interaction, dialogue, value. Journal of Business and Industrial Marketing, 19(2), 99-113.

Gupta, V.K., \& Batra, S. (2015). Entrepreneurial orientation and firm performance in Indian SMEs: Universal and contingency perspectives. International Small Business Journal, 123.

Hambrick, D.C. \& Mason, P.A. (1984). Upper echelons: The organization as a reflection of its top managers. Academy of Management Review, 9(2), 193-206.

Iqbal, S.M.J., Long, C.S., Fei, G.C., Ba'ith, S.M.L.A., \& Bukhari, S. (2015). Moderating effect of top management support on relationship between transformational leadership and project success. Pakistan Journal of Commerce and Social Sciences, 9(2), 540-567.

Jabeen, R., \& Mahmood, R. (2014). Effect of external environment on entrepreneurial orientation and business performance relationship. Social and Basic Sciences Research Review, 2(9), 394-403.

Kaplan, R.S., \& Norton, D.P. (1992). The balanced scorecard: Translating strategy into action. Harvard Business Review Press.

Kauffmann, C. (2005). Financing SMEs in Africa. OECD Development Centre. Paris: Organisation for Economic Co-operation and Development \& African Development Bank.

Kropp, F., Lindsay, N.J., \& Shoham, A., (2006). "Entrepreneurial, market, and learning orientations and international entrepreneurial business venture performance in South African firms", International Marketing Review, 23(5): 504-523.

Liu, S., Zhang , J., Keil, M., \& Chen, T. (2010). Comparing senior executive and project manager perceptions of IT project risk: a Chinese Delphi study. Information Systems Journal, , 20(4), 319-355.

Lo, M.C., Mohamad, A.A., Ramayah, T. \& Wang, Y.C. (2015). Examining the effects of leadership, market orientation and leader member exchange (LMX) on organizational performance. Inzinerine Ekonomika- Engineering Economics, 26(4), 409-421.

Lumpkin, G.T. \& Dess, G. (2001). "Linking Two Dimensions of Entrepreneurial Orientation to Firm Performance: The Moderating Role of Environment and Industry Life Cycle." Journal of Business Venturing 16: 429-451.

Lumpkin, G.T., \& Dess, G.G. (1996). Clarifying the entrepreneurial orientation construct and linking it to performance. Academy of Management Review, 21, 135-172.

Mwangi, R.M., Sejjaaka, P.S., Maina, P.R., Kairo, D., Rotich, A., Owino, E., \& Mindra, R. (2013). Constructs of Successful and Sustainable SME Leadership in East Africa By. Investment and Business Environment Research Fund. 
Noble, C.H., Sinha, R.K., \& Kumar, A. (2002). Market orientation and alternative strategic orientations: A longitudinal assessment of performance implications. Journal of Marketing, 66(4), 25-39.

Nunnaly, J.C. (1978), Psychometric Theory, McGraw-Hill, New York, NY.

Nwokah, N.G., \& Maclayton, D.W. (2006). Customer focus and business performance: The study of food and beverages organizations in Nigeria. Measuring Business Excellence, $10(4), 65-75$.

Olawale, F., \& Garwe, D. (2010). Obstacles to the growth of SMEs in South Africa. African Journal of Business Management, 4(5), 729-739.

Pinto, J., \& Slevin, D. (2006). Project critical success factors: The project-implementation profile. In D. I. Cleland \& R. Gareis (Eds.), Global Project Management Handbook: Planning, Organizing, and Controlling International Projects.

Project Management Institute (2008). A guide to the project management body of knowledge $\left(\right.$ PMBOK $^{\circledR}$ guide) (4th ed.). Newtown Square, PA: Project Management Institute.

Ramamoorthy, S. (2007). Lean Six Sigma Applications in Aircraft Assembly. Thesis Report.

Raravi, P., Bagodi, V., \& Mench, R.G. (2013). Critical Success Factors: Service Industries. SCMS Journal of Indian Management, 10(1).

Rauch, A., \& Frese, M. (2000). Psychological approaches to entrepreneurial success: A general model and an overview of findings. International Review of Industrial and Organizational Psychology, 15, 101-142.

Rauch, A., Wiklund, J., Lumpkin, G.T., \& Frese, M. (2009). Entrepreneurial orientation and business performance: An assessment of past research and suggestions for the future. Entrepreneurship Theory and Practice, 33(3), 761-787.

Rockart, J. (1979). Chief Executives Define Their Own Information Needs. In: Harvard

Rose, R.C., Kumar, N., \& Yen, L.L. (2006). Entrepreneurs Success Factors and Escalation of Small and Medium-sized Enterprises in Malaysia. Journal of Social Sciences, 2(3), 7480.

Salaheldin, I. (2009). Critical success factors for TQM implementation and their impact on performance of SMEs. International Journal of Productivity and Performance Management, 58(3), 215-237.

Saraph, J.V, Benson, P.G, Schroeder, R.G, (1989). "An instrument for measuring the critical factors of quality management', Decision Science, 20(4): 810-829.

Saravanan, R., \& Rao, K. (2006). Development and validation of an instrument for measuring total quality service. Total Quality Management and Business Excellence, 17(6), 733749. 
Sila, I. (2007). Examining the Effects of Contextual Factors on TQM and Performance through the Lens of Organizational Theories: An Empirical Study. Journal of Operations Management, 25(1), 83-109.

Somers, T.M., \& Nelson, K.G. (2004). A taxonomy of players and activities across the ERP project life cycle. Information \& Management, 41(3), 257-278.

Stam, E., Suddle, K., Hessels, J. \& Von Stel, A. (2006). High-growth entrepreneurs, public policies and economic growth. EIM Business \& Policy Research; SCALES Scientific Analysis of Entrepreneurship and SMEs: Zoetermeer.

Tehseen, S., Sajilan, S., Ramayah, T., \& Gadar, K. (2015). An Intra-Cultural Study of Entrepreneurial Competencies and SMEs Business Success in Whole Sale and Retail Industries of Malaysia:-A Conceptual Model. Review of Integrative Business and Economics Research, 4(3), 33.

Thandeka, R. K. (2008). SME success in South Africa. A critical Analysis of Entrepeneurial and Business Skills in SMEs in the Textile and Clothing Industry in Johannesburg, South Africa. Pretoria, South Africa: University of Pretoria.

Tomal, D.R., \& Jones, K. J. (2015). A comparison of core competencies of women and men leaders in the manufacturing industry. The Coastal Business Journal, 14(1): 13.

Turkyilmaz, A., Tatoglu, E., Zaim, S., \& Ozkan, C. (2010). TQM practices and business performance in SMEs. In V. Esposito Vinzi, W. W. Chin, J. Henseler, \& H. Wang (Eds.), Handbook of partial least squares (pp. 605-621 ). Verlag: Springer.

Tushabomwe-Kazooba, C. (2006). Causes of Small Business Failure in Uganda: A Case Study from Bushenyi and Mbarara Towns. African Studies Quarterly, 8(4).

Umble, E.J., Haft, R.R., \& Umble, M.M. (2003). Enterprise resource planning: implementation procedures and critical success factors. European Journal of Operational Research, 146, 241-257.

Utsch, A., \& Rauch, A. (2000). Innovativeness and initiative as mediators between achievement orientation and venture performance. European Journal of Work and Organizational Psychology, 9(1), 45-62.

Vassilakis, E., \& Besseris, G. (2009). An Application of TQM Tools at a Maintenance Division of a Large Aerospace Company. Journal of Quality in Maintenance Engineering, 15(1), $31-46$

Vyas, V., Raitani, S., Roy, A., \& Jain, P. (2015). Analysing critical success factors in small and medium enterprises banking. World Review of Entrepreneurship, Management and Sustainable Development, 11(1), 106-123.

Walter, A., Auer, M., \& Ritter, T. (2006). The impact of network capabilities and entrepreneurial orientation on university spin-off performance. Journal of Business Venturing, 21, 541567. 
Wang, C.L. (2008). "Entrepreneurial Orientation, Learning Orientation, and Firm Performance, Entrepreneurship Theory and Practice, 32(4): 635-657.

Wiklund, J., \& Shepherd, D. (2005). Entrepreneurial orientation and small business performance: a configurationally approach. Journal of Business Venturing, 20, 71-91.

Zhang, D., Linderman, K., \& Schroeder, R.G. (2012). The Moderating Role of Contextual Factors on Quality Management Practices. Journal of Operations Management, 30(1/2), $12-23$.

Ziggers, G.W., \& Henseler, J. (2015). The reinforcing effect of a firm's customer orientation and supply-base orientation on performance. Industrial Marketing Management, 52, 18-26. 